\title{
最近の菌学
}

\section{6. 口腔解剖}

ヒト歯肉付着上皮と歯小皮の構造について

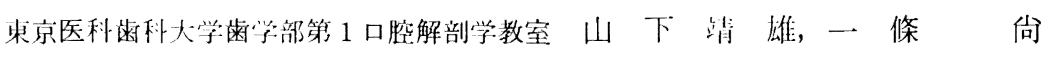

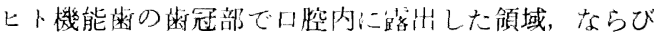
に歯肉溝のエナメ儿質表面にみられる画小皮は, エナメ 儿質の結晶からなる歯小皮第 1 膜（内㬝）と，微細な顆

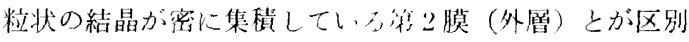
される。歯小皮は通常のエナィル質に比べて酸に強く, 第 2 膜は第 1 膜上りさらに強い膜となっている。歯頸部 で，付着上皮に㧍おわ机た部分のエナメ儿質表面に存在 する歯小皮に执いても，内外 2 層に区別され，内層の第 1 膜は歯冠部に2られるものと全く同栚な構造である が，第 2 膜は歯冠部のものとは異なり，電子染色される 有機成分を主体とした層である。しかしセメント・エナ メル境付近の第2膜には，その深部に微細な結晶の沈着 層がみられる場合もある。第2膜はセメント質の表面に も通常，上皮に㧍扮われている部分に限って認められる 場合もある。また第 2 膜は，場所によって厚さに差がる られ，時に欠如することもある。歯小皮第 1 膜はエナメ 儿質圭層の無小柱エナメル質の一部であるが，歯冠部な らびに付着上皮下の第 2 膜は，その結晶ならびに有機成 分の組成や由来に関してはいまだ不明な点が多い。

付着上皮の基底層付近深層の細胞は, mitochondria, free の ribosome などが比較的発達しままた rER も部分 的に観察されるほか, tonofilament も比較的豊富に存在 している。隣接の細胞はそれぞ机の細胞から伸びる小突 起に存在する desmosome によって互いに結合している。 さらに上皮細胞は中層から表層に向からにしたがい，一 般に扁平となり，また広い細胞間隙には多数の microvilli が観察され，ところどころに白血球などが介入して いる。細胞質内には free の ribosome が減少する一方, tonofilament が多くなり，それらの束も太くなってい る。之くに䍘面に付着する最表層ならびにその付近の細 胞においては, mitochondria, Golgi area, rER などの細
胞小器官がよく発達している。最表層の細胞の歯面に面 する細胞膜には，多数の細胞膜彎入や小简がみられる。 またこれらの細胞は約 $500 \AA ̊$ の幅をもつ基底膜様の層を 介して, hemidesmosome で雨小皮（第 1 膜または第 2 膜）あるいはセメント質に付着している。しかしこれら の細胞も歯肉满付近に近づくにしたがって, 細胞小器官 の変性像が多くみられるよらになり, 細胞質内には autophagic な lysosome や vacuole が多く観察されるように なるとともに, hemidesmosome の数も減少する。

歯面にほ注平行な断面で超薄切片を作製し，歯面に付 着している上皮細胞の付着細胞膜面付近を観察すると， hemidesmosome を構成している desmosomal plaque が 接続方向の断面で梁められ，これらが点状に散在してい る部分もあれば,隣接のものと融合し，全体としてdesmosomal plaque が網状をなしている部分もみられる。こ れらの構造物の間には, 大小の細胞膜彎入や小窝の横断 が観察される。また彎入部には, 膜によって囲まれた球 形ないし卵円形の顆粒状構造物がみられる場合もある。

画面に付着している上皮細胞に拈いては, tonofilament の束が歯に接する側の細胞膜に近いものほど細く, 内部に向からほど太くなっている。またこれらの tonofilament の束は, 歯面に平行な断面で観察すると, 全体 として網状に配列し，中にはこれらの眼網が円形をなす ように配列しているものもみられる。

いずれにしても付着上皮細胞に拈ける Golgi area その 他の細胞小器官など細胞内構造物の発達は, これらの付 着上皮が細菌侵入その他に対する化学的な防御機構を有 することと，細胞相互ならびに歯面へ付着することによ り，物理的な防御機構を有することに何らかの関連があ るものと思われる。 